\title{
Modulation of insulin receptor signalling by pancreastatin in HTC hepatoma cells
}

\author{
V. Sánchez-Margalet \\ Department of Medical Biochemistry and Molecular Biology, School of Medicine, Investigation Unit, Virgen Macarena Hospital, \\ University of Seville, Spain
}

\begin{abstract}
Summary Pancreastatin, a neuropeptide derived from chromogranin A, has a glycogenolytic and counterregulatory effect to insulin in the rat liver. This effect is mediated by calcium and protein kinase $\mathrm{C}$ activity. Our aim was to study the possible cross-talk between pancreastatin and the insulin signalling system, by using the well-studied insulin sensitive rat hepatoma HTC cells. First, we checked the counterregulatory effect of pancreastatin on insulin action. Pancreastatin dose-dependently inhibited insulin stimulated glycogen synthesis. This effect was not due to competition for insulin receptors. Moreover, when protein kinase $\mathrm{C}$ activation was blocked with staurosporine, this effect of pancreastatin was not observed. Next, we found a dose-dependent inhibition of insulin receptor autophosphorylation by pancreastatin. In addition, phosphorylation of the major substrates of insulin receptor in HTC, i.e. insulin-receptor substrate (IRS)-1/IRS-2 and p62 was also blunted and so was its association with p85 regulatory subunit of phos-
\end{abstract}

phatidylinositol-3-kinase. Moreover, the insulin activation of S6 kinase was also blocked by pancreastatin. Again, all these inhibitory effects of pancreastatin were prevented by staurosporine. Furthermore, pancreastatin produced Ser/Thr phosphorylation of insulin receptor by a staurosporine-sensitive mechanism. Finally, we checked the pancreastatin activation of protein kinase $\mathrm{C}$ in HTC cells and found that a "classical" isoform of this protein is translocated to the plasma membrane. These findings suggest that pancreastatin could exert its anti-insulin effect in the hepatocyte by interrupting the stimulation of early insulin receptor signalling as a result of phosphorylation. This interaction might have a role in the mechanisms of insulin resistance. [Diabetologia (1999) 42: 317-325]

Keywords Pancreastatin, chromogranin A, insulin receptor, insulin signalling, insulin action, hepatocyte, insulin resistance, Type II diabetes mellitus
Pancreastatin [1], a chromogranin A-derived neuropeptide [2] that was isolated first from the porcine pancreas is widely distributed throughout the neu-

Received: 9 February 1998 and in final revised form: 1 September 1998

Corresponding author: V. Sánchez-Margalet, Department Medical Biochemistry and Molecular Biology, School of Medicine, Av. Sanchez Pizjuan 4, E-41 009 Seville, Spain

Abbreviations: IRS-1, Insulin receptor substrate 1; IRS-2, insulin receptor substrate 2; PI3K, phosphatidylinositol 3-kinase; SH2 domains, Src homology 2 domains; IGF-1, insulin-like growth factor I; PKC, protein kinase C; DMEM, Dulbecco's modified Eagle's medium; Hepes, 4-(2-Hydroxyethyl)-1-piperazine-ethanesulfonic acid; BSA, bovine serum albumin. roendocrine system [3-6]. In islets, it appears to be localized to the insulin-containing beta cells, somatostatin containing delta cells [4] and glucagon containing alpha cells $[5,6]$. Post-secretory processing of chromogranin A also occurs [7, 8]. A pancreastatinlike sequence, homologous to porcine pancreastatin has been found in rat chromogranin A cDNA [9-11].

Pancreastatin has a number of effects in a variety of cell targets [12]. Thus, we have found a glycogenolytic effect [13-15] and a counterregulatory effect to insulin in the rat liver [16]. We have shown that its action in the liver is mediated by a specific receptor $[17$, 18] coupled to GTP binding proteins in the plasma membrane [17-19]. This receptor activates $\mathrm{G} \alpha_{\mathrm{q} / 11}$ in rat liver membranes [20] resulting in activation of 
phospholipase C (PLC) [21], a consequent increase in $\left[\mathrm{Ca}^{2+}\right]_{\mathrm{i}}$ and activation of protein kinase $\mathrm{C}$ (PKC) $[15$, 22]. As pancreastatin both inhibits insulin secretion and insulin action, it has been hypothesized that it could have a role in insulin resistance [23]. It has been found in high concentrations in subjects with Type II (non-insulin-dependent) diabetes and hypertension, conditions which are characterized by abnormal insulin secretion and insulin resistance [24-27], i. e. in the metabolic syndrome $X[28,29]$. In this context we studied the possible effects of pancreastatin on insulin receptor signal transduction using a hepatoma cell line (HTC cells) which had previously been used as a model for studying insulin action and receptor signalling both as wild type cells and cells transfected with the human insulin receptor [30, 31].

The insulin receptor is a tyrosine kinase [32] which, when activated by insulin binding undergoes autophosphorylation and phosphorylates intracellular protein substrates such as insulin receptor substrate 1 or insulin substrate 2 or both, and other proteins of about $60 \mathrm{kDa}$ [33]. Insulin receptor substrate proteins then interact with other molecules such as phosphatidylinositol-3-kinase (PI3K) via the Src homology 2 ( $\mathrm{SH} 2$ ) domains of its p85 regulatory subunit [33]. This results in an increase in PI3K activity which is important for many insulin-sensitive metabolic processes including stimulation of glucose transport [34], activation of the p70 S6 and Akt serine kinases [35, 36] and the stimulation of glycogen synthesis [37].

Our study was aimed to further elucidate the mechanism by which pancreastatin functions as a counterregulatory hormone in the hepatocyte. We describe its counterregulatory effect in HTC hepatoma cells and its cross-talk with the insulin signalling system.

\section{Materials and methods}

Materials. Pancreastatin was from Peninsula Laboratories (Merseyside, England). Antibodies to phosphotyrosine ( $\alpha$ PY) and the p85 subunit of PI3K ( $\alpha$-p85) were purchased from Upstate Biotechnology, Inc. (Lake Placid, N. Y., USA), to insulin receptor $\beta$-subunit, insulin-receptor substrate 1 (IRS-1) and insulin-receptor substrate 2 (IRS-2) were from Santa Cruz Biotechnology (Santa Cruz, Calif., USA), to phosphoserine and phosphothreonine from Sigma (Alcobendas, Madrid, Spain) and to "classical" PKC isoforms $(\alpha, \beta \mathrm{I}$ and $\beta$ II) from Calbiochem (AMS Biotecnologia, Madrid, Spain). Rabbit anti sera against $\beta_{\text {common }}$ subunit of $\mathrm{G}$ proteins were from DuPont NEN (Du Pont de Nemours, Germany). Protein $A$ and protein G-Sepharose were from Amersham Pharmacia Biotech (Barcelona, Spain). We purchased $\left[\gamma_{-}{ }^{32} \mathrm{P}\right] \mathrm{ATP}$ $(37-111 \mathrm{TBq} / \mathrm{mmol})$ and $\left[{ }^{14} \mathrm{C}\right]$ glucose $(250 \mathrm{Ci} / \mathrm{mmol})$ from DuPont NEN (Bad Homburg, Germany). Other chemicals were from Sigma unless specified otherwise.

Cells and preparation of soluble cellular lysates. Rat HTC hepatoma cells were kindly provided by Dr. I.D. Goldfine (UCSF, San Francisco, Calif., USA). Cells were prepared and maintained in H16 Dulbecco's modified Eagle's medium
(DMEM) as described previously [38, 39]. For experiments, cells were grown in $100 \mathrm{~mm}$ dishes to $90 \%$ confluence and serum starved for $16 \mathrm{~h}$. Typically, they were treated with insulin for $5 \mathrm{~min}$ at $37^{\circ} \mathrm{C}$. When other agonists and agents were included in the experiment, cells were preincubated for $10 \mathrm{~min}$ at $37^{\circ} \mathrm{C}$. Cells were then solubilized for $30 \mathrm{~min}$ at $4{ }^{\circ} \mathrm{C}$ in lysis buffer $(20 \mathrm{mmol} / \mathrm{l}$ Tris, $\mathrm{pH} 8,1 \%$ Nonidet P-40, $137 \mathrm{mmol} / \mathrm{l}$ $\mathrm{NaCl}, 1 \mathrm{mmol} / \mathrm{l} \mathrm{MgCl}, 1 \mathrm{mmol} / 1 \mathrm{CaCl}_{2}, 1 \mathrm{mmol} / \mathrm{l}$ dithiothreitol, $10 \%$ glycerol, $1 \mathrm{mmol} / \mathrm{l}$ phenylmethylsulphonyl fluoride, and $0.4 \mathrm{mmol} / \mathrm{l}$ sodium orthovanadate) $[38,39]$. Protein concentration was determined by the Bradford method using bovine serum albumin (BSA) as standard [40].

Glycogen synthesis studies. The HTC cells were plated in $100 \mathrm{~mm}$ dishes and grown to $90 \%$ confluence. They were serum-starved for $16 \mathrm{~h}$ in H16 DMEM containing $20 \mathrm{mmol} / \mathrm{l} 4$ (2-Hydroxyethyl)-1-piperazine-ethanesulfonic acid (Hepes) (pH 7.4) and $0.1 \%$ BSA. Cells were then incubated in Krebs Ringer with $20 \mathrm{mmol} / \mathrm{l}$ Hepes ( $\mathrm{pH} 7.4$ ), supplemented with $1 \% \mathrm{BSA}$ and $10 \mathrm{mmol} / \mathrm{l}$ glucose at $37^{\circ} \mathrm{C}$. After a $30 \mathrm{~min}$ preincubation period with or without insulin, $74 \mathrm{KBq}$ of $\left[{ }^{14} \mathrm{C}\right] \mathrm{glu}-$ cose were added and the incubation continued for $1 \mathrm{~h}$. Glycogen was isolated using $\mathrm{KOH}$ and ethanol extraction [16, 41], and counted in a liquid scintillation counter (Wallac 1490, Tur$\mathrm{ku}$, Finland).

$\left[{ }^{125}\right.$ I]Insulin binding studies. Cells were plated in 24-well plates $\left(2 \times 10^{5}\right.$ cells per well) and grown to $90 \%$ confluence. They were serum-starved for $16 \mathrm{~h}$ in H16 DMEM containing $20 \mathrm{mmol} / 1$ Hepes ( $\mathrm{pH} 7.4$ ) and $0.1 \%$ BSA as shown previously for insulin-like growth factor-1 binding [39]. Cells were then incubated with $\left.{ }^{125} \mathrm{I}\right]$ insulin $(20000 \mathrm{cpm} /$ well $)$ and varying concentrations of unlabelled insulin or pancreastatin for $2 \mathrm{~h}$ at $20^{\circ} \mathrm{C}$. Finally, cells were rinsed with ice-cold phosphate buffered saline (PBS) and lysed in $0.03 \%$ sodium dodecyl sulphate (SDS) for measurement of cell-associated radioactivity [39]. Nonspecific binding was determined in the presence of 1 $\mu \mathrm{mol} / \mathrm{l}$ unlabelled insulin.

Immunoprecipitation and western blotting analysis. Soluble cellular lysates ( $2 \mathrm{mg}$ of protein) were precleared with $50 \mu \mathrm{l}$ of protein A-Sepharose (Pharmacia, Uppsala, Sweden) for $2 \mathrm{~h}$ at $4^{\circ} \mathrm{C}$ by end-over-end rotation. The precleared cellular lysates were incubated with appropriate antibodies for $3 \mathrm{~h}$ at $4{ }^{\circ} \mathrm{C}$ [38]. Next, $50 \mu \mathrm{l}$ of protein A-Sepharose was added to immune complexes and incubation was continued for $2 \mathrm{~h}$ at $4{ }^{\circ} \mathrm{C}$. The immunoprecipitates were washed three times with lysis buffer. We added $40 \mu \mathrm{l}$ of SDS-stop buffer containing $100 \mathrm{mmol} / \mathrm{l} \mathrm{di}$ thiothreitol to the immunoprecipitates followed by boiling for $5 \mathrm{~min}$. The soluble supernatants were then resolved by SDSPAGE and electrophoretically transferred onto polyvinyldifluoride membranes [38]. The membranes were blocked with trisbuffered saline- $0.05 \%$ Tween 20 (TBST) containing $5 \%$ nonfat dry milk for $1 \mathrm{~h}$ at $23^{\circ} \mathrm{C}$. The blots were then incubated with primary antibody for $1 \mathrm{~h}$, washed in TBST, and further incubated with secondary antibodies linked to horseradish peroxidase. Western blottings were then made visible by enhanced chemiluminescence kit (ECL) (Amersham, Buckinhamshire, England) [42]. A more sensitive kit (ECL plus) was used to make blots of anti-IRS-1 and anti-IRS-2 immunoprecipitates visible. The bands obtained in the western blots were scanned and then analysed by the PCBAS2.0 program.

Activation of p70 S6 kinase. Cells were treated for $30 \mathrm{~min}$ at $37^{\circ} \mathrm{C}$ with or without $100 \mathrm{nmol} / \mathrm{l}$ insulin in the presence or absence of $100 \mathrm{nmol} / \mathrm{l}$ pancreastatin, with or without $100 \mathrm{nmol} / \mathrm{l}$ staurosporine. When pancreastatin or staurosporine was used, 
they were added $10 \mathrm{~min}$ before the addition of insulin. At the end of the incubation, cells were made soluble in S6 kinase lysis buffer and assayed for their S6 kinase activity with Artemia salina shrimp egg 40S ribosomes as substrate [34]. We analysed S6 phosphorylation by SDS-PAGE followed by autoradiography [34].

Activation of $P K C$. Cells were treated for $10 \mathrm{~min}$ at $37^{\circ} \mathrm{C}$ with or without $100 \mathrm{nmol} / \mathrm{l}$ pancreastatin. Subsequently, cells were lysed in the same lysis buffer described above but without Triton X-100 for membrane preparation. Then, cells were centrifuged at $40000 \times g$ for 30 min and the pellet was made soluble with lysis buffer containing $1 \%$ Triton X-100. Lysates were next centrifuged at $14000 \times g$ for $15 \mathrm{~min}$ and the supernatant was taken and analysed by western blotting as described previously [43] to detect pancreastatin-induced PKC translocation.

\section{Results}

Pancreastatin inhibits insulin-stimulated glycogen synthesis and this effect is blocked by staurosporine. We used a range of concentrations of pancreastatin to investigate its counterregulatory effect on insulinstimulated glycogen synthesis in HTC cells. Basal [U- $\left.{ }^{14} \mathrm{C}\right]$ glucose incorporation into glycogen was $25 \pm$ $2 \mathrm{pmol} / \mathrm{mg}$ protein and rose if stimulated by insulin $65 \%$ over the control to $41 \pm 3 \mathrm{pmol} / \mathrm{mg}$ protein. Pancreastatin dose-dependently inhibited the insulinstimulated increase of glucose incorporation above basal concentrations. Its maximum effect was reached at a concentration of $100 \mathrm{nmol} / \mathrm{l}$ (Fig.1). Pancreastatin had no effect on basal glycogen synthesis.

Incubation of HTC cells with increasing concentrations of pancreastatin to compete for insulin binding had no effect, even at micromolar concentration (Fig.2), with no differences in insulin affinity for its receptor.

Staurosporine [44] completely abolished the inhibitory effect of pancreastatin on insulin-stimulated glucose incorporation into glycogen (Fig.1). The dose of stauroporine $(100 \mathrm{nmol} / \mathrm{l})$ is within the range for its specific action on PKC. Therefore, in HTC cells, PKC activity seems to be necessary for this effect of pancreastatin.

Inhibition by pancreastatin of insulin-stimulated tyrosine phosphorylation of insulin receptor and insulin receptor substrates associated with PI3K. To examine the effect of pancreastatin on insulin-stimulated tyrosine autophosphorylation of insulin receptors, cells were preincubated with different concentrations of pancreastatin prior to stimulation for 5 min with 100 $\mathrm{nmol} / \mathrm{l}$ insulin. Cell extracts were subjected to immunoprecipitation with insulin receptor-specific antibody. Pancreastatin inhibited insulin-stimulated autophosphorylation of the insulin receptor $\beta$-subunit in a dose-dependent manner (up to $83 \%$; Fig. 3 ). It had no effect on basal tyrosine phosphorylation of the insulin receptor (data not shown).

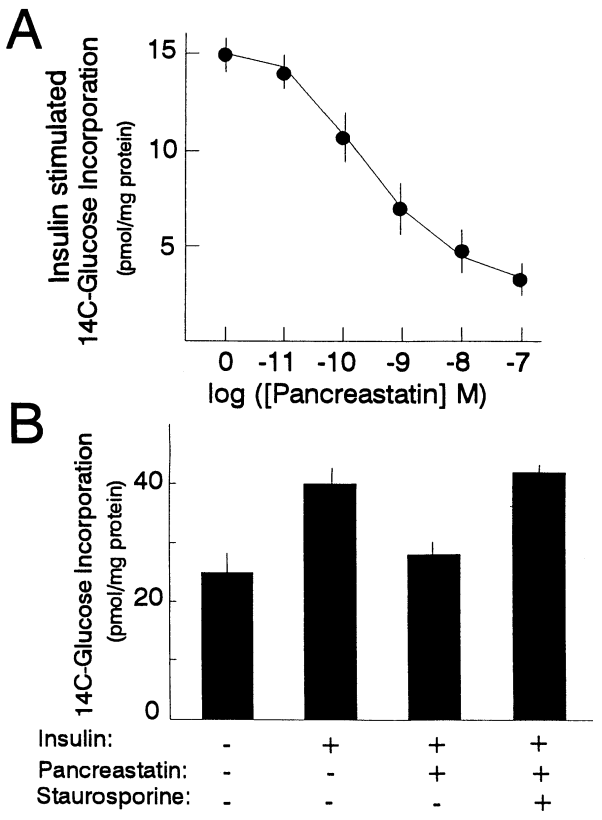

Fig. 1. Pancreastatin inhibits-insulin stimulated glycogen synthesis and this effect is blocked by staurosporine. A) Cells were incubated in the presence of $100 \mathrm{nM}$ insulin and different concentrations of pancreastatin for $30 \mathrm{~min}$ and further incubated with $74 \mathrm{KBq}{ }^{14} \mathrm{C}$-glucose for $1 \mathrm{~h}$. Results are the values above basal levels. B) Cells were preincubated during $30 \mathrm{~min}$ in the absence or the presence of $100 \mathrm{nM}$ insulin, $100 \mathrm{nM}$ pancreastatin or $100 \mathrm{nM}$ staurosporine. Cells were further incubated for $1 \mathrm{~h}$ in the presence of $74 \mathrm{KBq}{ }^{14} \mathrm{C}$-glucose. Data are the means \pm SEM of four different experiments

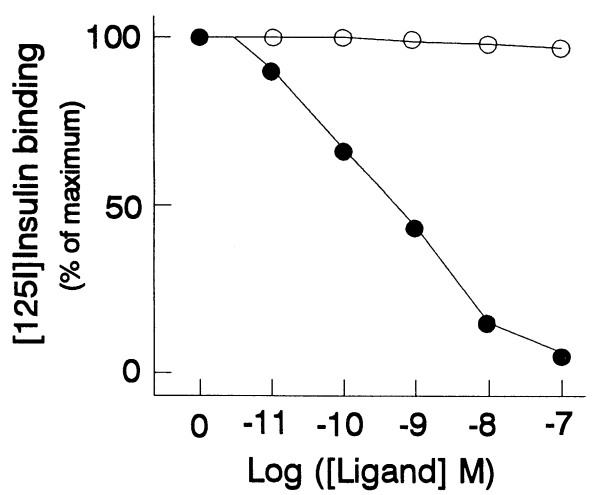

Fig. 2. Effect of insulin and pancreastatin on $\left[{ }^{125} \mathrm{I}\right]$ insulin binding to HTC cells. HTC cells were incubated for $2 \mathrm{~h}$ at $20^{\circ} \mathrm{C}$ with $\left[{ }^{125} \mathrm{I}\right]$ insulin and varying concentrations of either unlabelled insulin $(0)$ or pancreastatin $(\bigcirc)$. The cells were then washed and solubilized. Radioactivity in solubilized cell lysates was then counted in a $\gamma$-counter. [ ${ }^{125} \mathrm{I}$ ] insulin binding to cells in the absence of unlabelled ligand was normalized to $100 \%$. A representative experiment of three separate experiments run in triplicate is shown

We also studied postreceptor signalling. Pancreastatin dose-dependently inhibited the tyrosine phosphorylation of insulin receptor substrates (IRS-1/ IRS-2 and p62) associated with PI3K (up to $88 \%$ IRS-1/IRS-2; and up to $91 \%$ p62; Fig. 4). Pancreasta- 


\section{IP Ab: Anti-IR \\ WB Ab: Anti-PY}

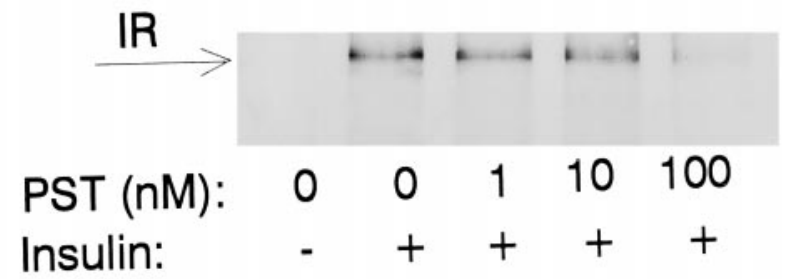

Fig.3. Dose-dependent effect of pancreastatin on insulin-stimulated phosphorylation of the beta subunit of insulin receptor. HTC cells were preincubated with different concentrations of pancreastatin for $10 \mathrm{~min}$ and further incubated with $100 \mathrm{nmol} / \mathrm{l}$ insulin for $5 \mathrm{~min}$. Cells were then washed and solubilized. Cell lysates were next immunoprecipitated with $\alpha$-IR, subject to SDS-PAGE and analysed by western blotting with $\alpha$-PY. IR, insulin receptor beta subunit; IP-Ab, immunoprecipitating antibody; WB-Ab, western blotting antibody. An experiment representative of 3 is shown

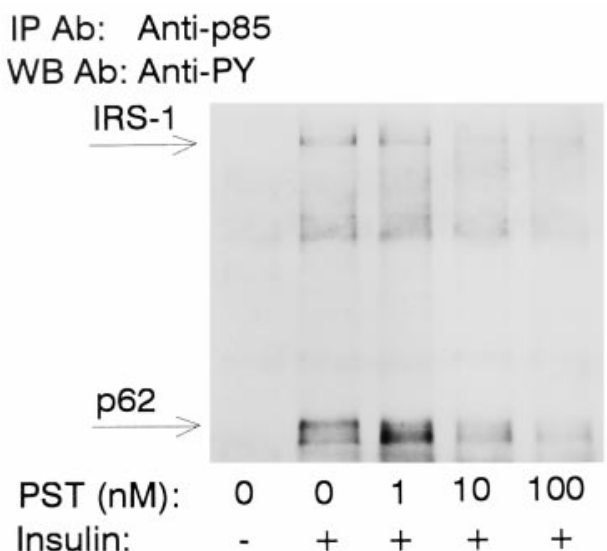

Fig. 4. Dose-dependent effect of pancreastatin on insulin-stimulated phosphorylation-association of substrates of insulin receptor with $\mathrm{p} 85$, the regulatory subunit of phosphatidyl-3-kinase. HTC cells were preincubated with different concentrations of pancreastatin for $10 \mathrm{~min}$ and further incubated with $100 \mathrm{nmol} / \mathrm{l}$ insulin for $5 \mathrm{~min}$. Cells were then washed and solubilized. Cell lysates were next immunoprecipitated with $\alpha$-p85, subject to SDS-PAGE and analysed by western blotting with anti-phosphotyrosine antibody. IRS-1, insulin receptor substrate-1/insulin receptor substrate-2; p62, 60-70 kDa insulin receptor substrate; IP-Ab, immunoprecipitating antibody; WB-Ab, western blotting antibody. An experiment representative of the other 3 is shown

tin alone had no effect on basal tyrosine phosphorylation of these substrates (data not shown).

Effect of PKC inhibitor staurosporine on pancreastatin-modulated insulin receptor function. To evaluate the potential mechanism of the inhibitory effect of pancreastatin on insulin receptor function, we tested the PKC inhibitor, staurosporine, since this treatment abolished the metabolic effect of pancreastatin in

\section{IP Ab: Anti-IR \\ WB Ab: Anti-PY}

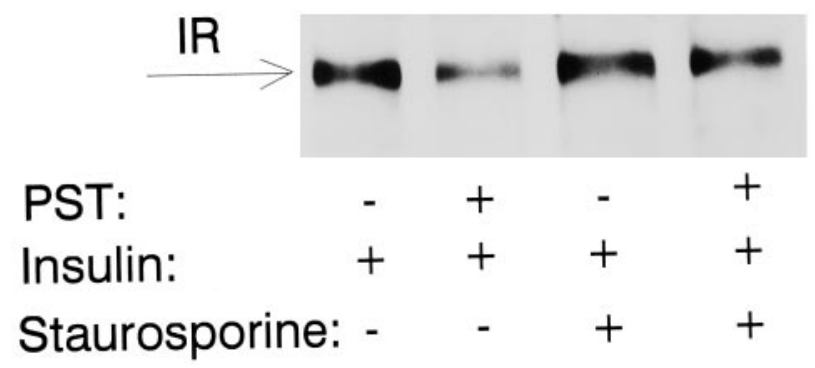

Fig. 5. Pancreastatin inhibition of insulin-dependent autophosphorylation of insulin receptor is blocked by staurosporine. Cells were incubated with or without $100 \mathrm{nmol} / \mathrm{l}$ pancreastatin and with or without $100 \mathrm{nmol} / \mathrm{l}$ staurosporine for $10 \mathrm{~min}$ prior to being stimulated with $100 \mathrm{nmol} / \mathrm{l}$ insulin for $5 \mathrm{~min}$. Cells were then washed and solubilized. Cell lysates were next immunoprecipitated with $\alpha$-IR, subject to SDSPAGE and analysed by western blotting with $\alpha$-PY. IR, insulin receptor beta subunit; IP-Ab, immunoprecipitating antibody; $\mathrm{WB}-\mathrm{Ab}$, western blotting antibody. Similar results were obtained in the other 2 experiments

these cells (Fig.1) and there was no competition for binding sites (Fig. 2). Treating HTC cells with staurosporine almost completely restored (up to $80 \%$ ) the insulin-stimulated insulin receptor autophosphorylation inhibited by pancreastatin (Fig. 5). It should be noted that the PKC inhibitor itself had no effect on insulin receptor tyrosine phosphorylation in either the basal (not shown) or the insulin-stimulated state (Fig. 5).

Consistent with the previous results observed in insulin receptor phosphorylation, the effect of pancreastatin on insulin-stimulated phosphorylation of downstream substrates, IRS-1/IRS-2 and p62, associated with PI3K was also reversed by staurosporine (Fig. 6), suggesting that insulin receptor tyrosine kinase activity was almost completely restored and further supporting the hypothesis that pancreastatin functions through stimulation of PKC. Staurosporine seems however to differentially regulate pancreastatin action on IRS-1/IRS-2 and p62 phosphorylation, suggesting that different mechanisms of cross-talk (other than PKC) could interfere with insulin signalling.

Next, we studied the possible differential regulation of IRS- 1 and IRS-2 by pancreastatin in HTC cells by immunoprecipitation with specific antibodies (Fig. 7). Basal IRS-2 tyrosine phosphorylation seemed to be higher than IRS-1 tyrosine phosphorylation. Nevertheless, both IRS-1 and IRS-2 tyrosine phosphorylation were increased by insulin stimulation. Pancreastatin can inhibit the effect of insulin on the tyrosine phosphorylation of both IRS-1 and IRS-2. As expected, this effect was blocked by staurosporine 
IP Ab: Anti-p85

WB Ab: Anti-PY

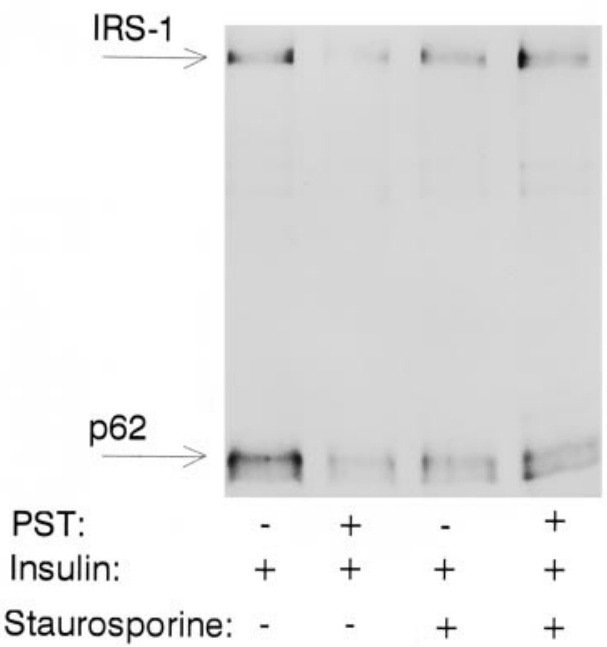

Fig. 6. Staurosporine blocks pancreastatin inhibition of insulin-stimulated phosphorylation-association of substrates of insulin receptor with $\mathrm{p} 85$, the regulatory subunit of phosphatidylinositol-3-kinase. Cells were incubated with or without 100 $\mathrm{nmol} / \mathrm{l}$ pancreastatin and with or without $100 \mathrm{nmol} / \mathrm{l}$ staurosporine for $10 \mathrm{~min}$ prior to being stimulated with $100 \mathrm{nmol} / \mathrm{l}$ insulin. Cells were then washed and solubilized. Cell lysates were next immunoprecipitated with $\alpha$-p85, subject to SDS-PAGE and analysed by western blotting with anti-phosphotyrosine antibody. IRS-1, insulin receptor substrate-1/insulin receptor substrate-2; p62, 60-70 kDa insulin receptor substrate; IP-Ab, immunoprecipitating antibody; WB-Ab, western blotting antibody. Similar results were obtained in 3 experiments

(up to $90 \%$ ), suggesting the role of PKC activation by pancreastatin in the cross-talk with insulin receptor signalling.

Pancreastatin inhibits insulin-stimulated S6 kinase activity and this effect is blocked by staurosporine. To further study the effect of pancreastatin in downstream signalling molecules, we studied its effect on the PI3K dependent S6 kinase when stimulated by insulin, a later event in the signalling cascade known to be important for the regulation of glycogen synthesis [37]. Pancreastatin blocked S6 kinase activation by insulin treatment in HTC cells $(75 \%$ inhibition; Fig. 8). Again, PKC inhibition with staurosporine completely abolished this effect of pancreastatin (Fig. 5, 6 and 7).

Pancreastatin stimulates Ser/Thr phosphorylation of insulin receptor. To further evaluate the possible mechanism of cross-talk between pancreastatin and insulin receptor signalling, we studied the phosphorylation of insulin receptors in serine and threonine residues, by western blots with specific antibodies in insulin receptor immunoprecipitates. Pancreastatin (100 nmol/l) increased serine phosphorylation as well as threonine phosphorylation (Fig.9) after
A

IP Ab: Anti-IRS-1

WB Ab: Anti-PY

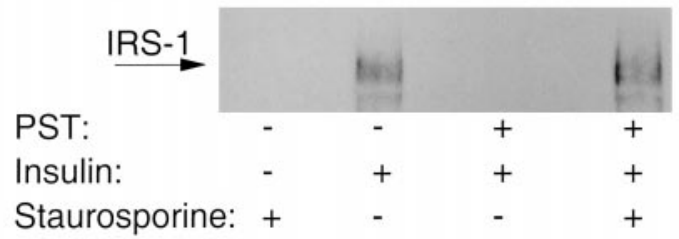

B

IP Ab:

Anti-IRS-2

WB Ab: Anti-PY
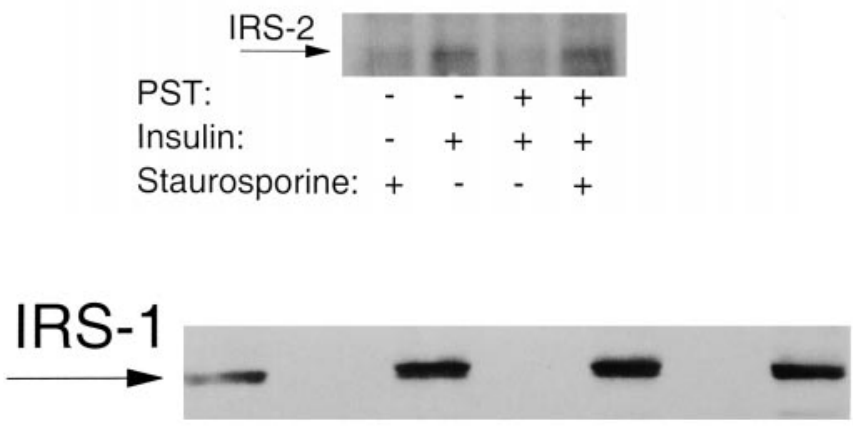

IRS-2

Fig. 7A, B. Pancreastatin effect on insulin-stimulated IRS-1 and IRS-2 phosphorylation is blocked by staurosporine. Cells were incubated with or without $100 \mathrm{nmol} / \mathrm{l}$ pancreastatin and with or without $100 \mathrm{nmol} / \mathrm{l}$ staurosporine for $10 \mathrm{~min}$ prior to being stimulated with $100 \mathrm{nmol} / \mathrm{l}$ insulin. Cells were then washed and solubilized. Cell lysates were next immunoprecipitated with $\alpha$-IRS-1 (A) or $\alpha$-IRS-2 (B), subject to SDS-PAGE and analysed by western blotting with anti-phosphotyrosine antibody (A, B). The membrane were reprobed with antiIRS-1 and anti-IRS-2 (lower panel). IRS-1, insulin receptor substrate-1, IRS-2, insulin receptor substrate-2; IP-Ab, immunoprecipitating antibody; WB-Ab, western blotting antibody. Similar results were obtained in 2 other experiments

$10 \mathrm{~min}$ incubation. These effects were decreased (75\%) by inhibiting PKC activity with staurosporine, which had no effect on basal phosphorylation of insulin receptor.

Pancreastatin stimulates "classical" $P K C$ in HTC cells. Panceastatin induced an increase of PKC in the plasma membrane, as expected from the previously described effect on $\mathrm{Ca}^{2+}$ and diacylglycerol production in rat hepatocytes [15, 22] (Fig. 10). Furthermore, the PKC isoform activated by pancreastatin belongs to the family of classical isoforms $(\alpha, \beta \mathrm{I}$ and $\beta \mathrm{II})$ as assessed by specific immunoblot (Fig. 10). 


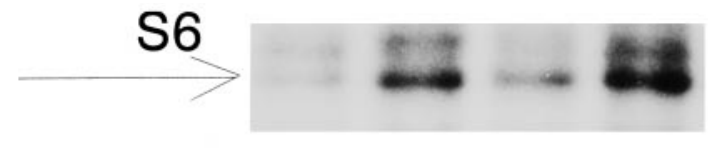

PST:

Insulin:

Staurosporine: - $\quad-\quad-\quad+$

Fig. 8. Pancreastatin effect on insulin-stimulated p70 S6 kinase activation is inhibited by staurosporine. Cells were incubated for $30 \mathrm{~min}$ with or without $100 \mathrm{nmol} / \mathrm{l}$ insulin in the presence or absence of pancreastatin and staurosporine. Cells were then solubilized. The soluble cell lysates were next assayed for S6 kinase activity in a reaction buffer containing $40 \mathrm{~S}$ ribosomal subunits and $\left[\gamma_{-}{ }^{32} \mathrm{P}\right] \mathrm{ATP}$ as described in Materials and Methods. S6 phosphorylation was analyzed by SDS-PAGE and subsequent autoradiography. This experiment was repeated two times with similar results

\section{A IP Ab: Anti-IR WB Ab: Anti-PSer}

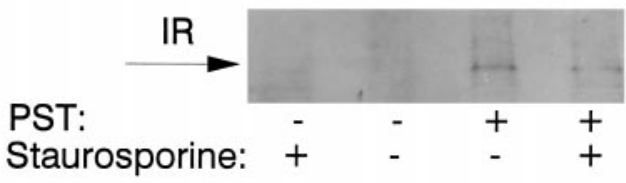

B

IP Ab: Anti-IR

WB Ab: Anti-Pthr
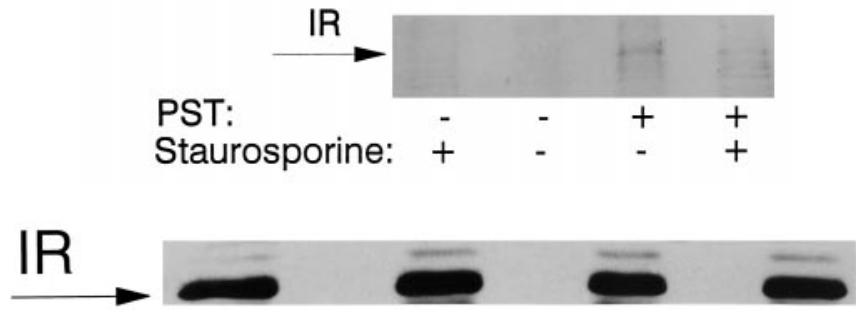

Fig.9A, B. Pancreastatin stimulates Ser/Thr phosphorylation of insulin receptor. Cells were incubated for $10 \mathrm{~min}$ with or without $100 \mathrm{nmol} / \mathrm{l}$ pancreastatin, with or without $100 \mathrm{nmol} / \mathrm{l}$ staurosporine. Cells were then washed and solubilized. Cell lysates were next immunoprecipitated with $\alpha$-IR, subject to SDS-PAGE and analysed by western blotting with $\alpha$-Phosphoserine (A), $\alpha$-Phosphothreonine (B) or $\alpha$-IR (lower panel). IR, insulin receptor beta subunit; IP-Ab, immunoprecipitating antibody; WB-Ab, western blotting antibody. This experiment was repeated two times with similar results

\section{Discussion}

In this study we show that treating HTC hepatoma cells with pancreastatin inhibits both insulin action and signalling. We had previously found the glycogenolytic effect of pancreastatin in rat liver [13-15] and its counterregulatory effect to insulin in rat hepa-
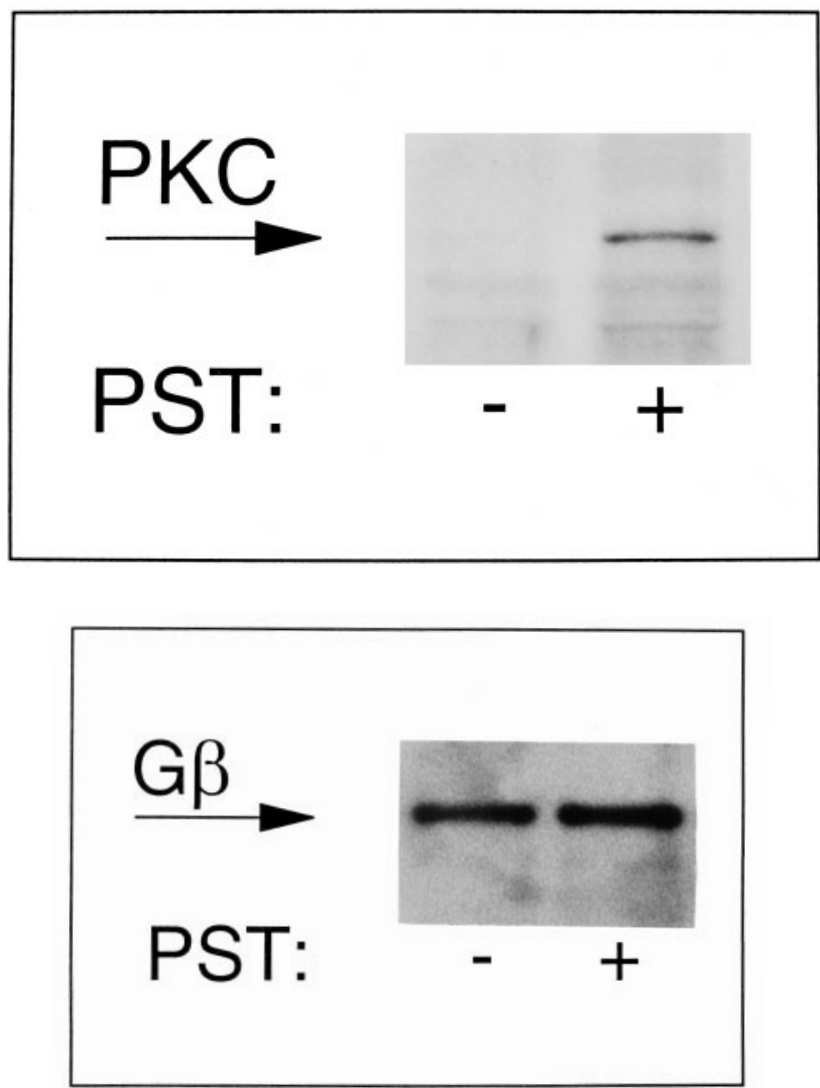

Fig. 10. Pancreastatin induced translocation of "classical" PKC isoforms. Cells were incubated for $10 \mathrm{~min}$ with or without $100 \mathrm{nmol} / \mathrm{l}$ pancreastatin and plasma membrane fraction was solubilized, subject to SDS-PAGE and analysed by western blotting with specific antibodies against classical PKC isoforms $(\alpha, \beta \mathrm{I}, \beta \mathrm{II})$ (upper panel), and antibodies against $\beta$ subunit of $\mathrm{G}$ proteins (lower panel). A western blot representative of 3 experiments is shown

tocytes [16]. After interacting with specific receptors $[17,18]$, pancreastatin activates PLC by activation of $\mathrm{G}$ proteins in the plasma membrane [19-22]. It seems the PLC- $\beta 3$ isoform is specifically activated by pancreastatin receptors and mediated by $\mathrm{G}_{11}$ [44]. Increased circulating pancreastatin concentrations have been found in patients with Type II diabetes [25], gestational diabetes [45] and in hypertensive patients [26]. These data suggest that pancreastatin could have a role in the insulin resistance syndrome.

Moreover, we have recently found that plasma pancreastatin-like immunorreactivity correlates with plasma norepinephrine in essential hypertension [28] and gestational diabetes [45]. Since insulin resistance and the sympathoadrenal system are involved in the metabolic abnormalities associated with hypertension [46] we proposed that pancreastatin might contribute to the counterregulatory effect of catecholamines in pathophysiological conditions, when catecholamines concentrations are increased.

Even though insulin receptors appear to exhibit normal binding characteristics in most patients with 
insulin resistance, impaired activation of intrinsic tyrosine kinase activity of the insulin receptor has been observed. This defect is probably responsible for the pathogenesis of cellular insulin resistance [47]. The molecular mechanisms responsible for the reduced activation of the insulin receptor kinase in patients with Type II diabetes and other insulin resistant subjects have, however, not yet been identified. Therefore, modulators of insulin receptor function should be taken into account when looking for mechanisms of insulin resistance. Other agonists such as catecholamines, adenosine [48], angiotensin [49] or bradykinin [50] are known to be able to regulate insulin receptor function. Activation of PKC, which then Ser/Thr phosphorylates the insulin receptor, seems to be the molecular mechanism involved in many cases [51-53].

Pancreastatin seems to negatively modulate insulin receptor signalling. Thus, insulin receptor autophosphorylation upon insulin binding was decreased by preincubation with pancreastatin and consequently its tyrosine kinase activity was blunted. This effect was not due to changes in insulin affinity for its receptor or to competition with insulin for common binding sites. The same experiments were repeated, but cell extracts were immunoprecipitated with antisera to $\mathrm{p} 85$, the regulatory subunit of PI3K that has been shown previously to bind to phosphorylated substrates of insulin receptor via its $\mathrm{SH} 2$ domains in this cell line $[34,38,42]$. We also checked the basal and insulin-stimulated phosphorylation state of insulin receptor substrate-1 (IRS-1) and insulin receptor substrate-2 (IRS-2) in the cell lysate by using an ultrasensitive method of chemiluminescence (ECL plus). Insulin stimulates tyrosine phosphorylation of both IRS- 1 and IRS-2 and this effect is inhibited by pancreastatin. The decreased phosphorylated insulin receptor substrates associated with PI3K most likely reflect a decrease in tyrosine phosphorylation by the insulin receptor $\beta$-subunit since the association is mediated by $\mathrm{SH} 2$ domains of $\mathrm{p} 85$, the regulatory subunit of PI3K. Moreover, the association of phosphorylated substrates with PI3K is the important step for transmitting the signal downstream in the cell. Thus, the insulin-stimulated activation of S6 kinase was also inhibited by pancreastatin.

To evaluate the potential mechanism of this inhibitory effect of pancreastatin we used a PKC inhibitor, staurosporine [54]. Protein kinase $\mathrm{C}$ is known to modulate insulin action in other cultured hepatoma cells [51]. These effects of pancreastatin seem to be also mediated by Ser/Thr phosphorylation because PKC inhibition with staurosporine was able to block all the signalling effects. Serine and threonine phosphorylation of insulin receptors was observed after stimulation with pancreastatin and this effect was impaired by staurosporine. These results suggest that insulin receptor Ser/Thr phosphorylation could be one of the mechanisms underlying the counterregulatory ef- fect of pancreastatin as described previously for other hormones [49-50]. Pancreastatin acts through specific membrane receptors $[17,18]$ whose mechanism of signal transduction has still to be fully elucidated [19]. Pancreastatin-induced activation of PKC has, however, been shown in rat hepatocytes [22]. We have confirmed the activation of PKC by pancreastatin in HTC cells by testing the subcellular distribution of classical PKC isoforms. Thus, when we checked PKC activation by pancreastatin in HTC cells by translocation assay, we found that classical PKC isoforms were stimulated by pancreastatin and, therefore, could be responsible for the phosphorylation of insulin receptors and the inhibition of signalling. We do not know yet which specific PKC isoform is activated by pancreastatin in this system but the isoforms beta 1 and beta 2 have been shown to be candidates for insulin receptor inhibition [55].

Our findings also indicate that stoichiometry could be important in assessing the relevance of pancreastatin counterregulatory action. Thus, in HTC cells transfected with human insulin receptor the effect of pancreastatin described here was not observed (data not shown). Transfected cells express five times more insulin receptors than wild type cells (50 000 and 10000 sites respectively). Taking into account that the number of pancreastatin receptors in the hepatocytes is about 5000 per cell [17], and HTC cells have a similar number, these results are to be expected. On the other hand, the data obtained could be physiologically relevant since the counterregulatory effects of pancreastatin were observed even at concentrations close to those of plasma pancreastatinlike observed in some insulin resistant patients (0.1-1 nmol/1) [26].

In conclusion, the data obtained agree with the proposed role of pancreastatin as a modulator of insulin action and signalling and possibly provide some clues for a better understanding of the mechanisms of insulin resistance.

Acknowledgements. We are grateful to I.D. Goldfine (UCSF, San Francisco) for providing the HTC cells. This work was supported by grant DGICYT 94/1437 from the Ministry of Education (Spain) and Fondo de Investigación Sanitaria, FIS 96/1411 from the Ministry of Health (Spain).

\section{References}

1. Tatemoto K, Efendic S, Mutt V, Makk G, Feistner GJ, Barchas JC (1986) Pancreastatin, a novel pancreatic peptide that inhibits insulin secretion. Nature 324: 476-478

2. Iancangelo AL, Fischer-Colbrie R, Koller KJ, Brownstein MJ, Eiden LE (1988) The sequence of porcine chromogranin A messenger RNA demonstrates chromogranin A can serve as the precursor for the biologically active hormone, pancreastatin. Endocrinology 155: 2339-2347

3. Iancangelo AL, Affolter HU, Eiden LE, Herbert E, Grimes M (1986) Bovine chromogranin A sequence and 
distribution of its messenger RNA in endocrine tissues. Nature 323: 82-86

4. Ravazzola M, Efendic S, Östenson CG, Tatemoto K, Hutton JC, Orci L (1988) Localization of pancreastatin immunoreactivity in porcine endocrine cells. Endocrinology 123: 227-229

5. Lamberts R, Schmidt WE, Creutzfeldt W (1990) Light and electron microscopical immunocytochemical localization of pancreastatin-like immunoreactivity in porcine tissues. Histochemistry 93: 369-380

6. Curry WJ, Johnston CF, Shaw C, Buchanan KD (1991) Distribution and partial characterization of immunoreactivity to the putative C-terminus of rat pancreastatin. Regul Pept 30: 207-219

7. Simon JP, Bader MF, Aunis D (1989) Proteolytic processing of CGA in cultured chromaffin cells. Biochem Biophys Acta 1051: 123-130

8. Watkinson A, O'Sullivan A, Burgoyne R, Dockray G (1990) Differential accumulation of catecholamines, proenkephalin- and CGA-derived peptides in the medium after chronic nicotine stimulation of cultured bovine adrenal chromaffin cells. Peptides 11: 435-441

9. Abood ME, Eberwine JH (1990) Characterization and regulation of a cDNA clone for rat pancreastatin. Biochem Biophys Res Commun 167: 1079-1085

10. Iancangelo AL, Okayama H, Eiden LE (1988) Primary structure of rat chromogranin $\mathrm{A}$ and distribution of its mRNA. FEBS Lett 227: 115-121

11. Parmer RJ, Koop AH, Handa MT, O’Connor DT (1989) Molecular cloning of chromogranin A from rat pheochromocytoma cells. Hypertension 14: 435-444

12. Sánchez-Margalet V, Lucas M, Goberna R (1996) Pancreastatin: further evidence for its consideration as a regulatory peptide. J Mol Endocrinol 16: 1-8

13. Sánchez V, Calvo JR, Goberna R (1990) Glycogenolytic effect of pancreastatin in the rat. Biosci Rep 10: 87-91

14. Sánchez V, Lucas M, Calvo JR, Goberna R (1992) Glycogenolytic effect of pancreastatin in isolated rat hepatocytes is mediated by a cyclic-AMP-independent $\mathrm{Ca}^{2+}$-dependent mechanism. Biochem J 284: 659-662

15. Sánchez-Margalet V, Lucas M, Goberna R (1993) Pancreastatin increases free cytosolic $\mathrm{Ca}^{2+}$ in rat hepatocytes involving both pertussis-toxin-sensitive and insensitive mechanisms. Biochem J 294: 439-442

16. Sánchez-Margalet V, Goberna R (1994) Pancreastatin inhibits insulin-stimulated glycogen synthesis but not glycolysis in rat hepatocytes. Regul Pept 51: 215-220

17. Sánchez-Margalet V, Valle M, Goberna R (1994) Receptors for pancreastatin in rat liver membranes: molecular identification and characterization by covalent cross-linking. Mol Pharmacol 46: 24-29

18. Sánchez-Margalet V, Santos-Alvarez J (1997) Solubilization and molecular characterization of pancreastatin receptors from rat liver membranes. Endocrinology 138: 1712-1718

19. Sánchez-Margalet V, Lucas M, Goberna R (1996) Pancreastatin action in the liver: dual coupling to different $\mathrm{G}$ proteins. Cell Signal 8: 9-12

20. Santos-Alvarez J, González-Yanes C, Sánchez-Margalet V (1998) Pancreastatin receptor is coupled to a guanosine triphosphate-binding binding protein of the $G_{q / 11} \alpha$ family in rat liver membranes. Hepatology 27: 608-614

21. Sánchez-Margalet V, Goberna R (1994) Pancreastatin activates pertussis toxin-sensitive guanylate cyclase and pertussis toxin-insensitive phospholipase $\mathrm{C}$ in rat liver membranes. J Cell Biochem 55: 173-181

22. Sánchez-Margalet V, Lucas M, Goberna R (1994) Pancreastatin activates protein kinase $\mathrm{C}$ by stimulating the forma- tion of 1,2-diacylglycerol in rat hepatocytes. Biochem J 303: 51-54

23. Sánchez-Margalet V, Goberna R (1993) Pancreastatin, a new peptide associated with essential hypertension and hyperinsulinemia. In: Galteau MM, Henny J, Siest G (eds) Biologie Prospective. John Libbey Eurotext, Paris pp 575-580

24. DeFronzo RA, Bonadonna RC, Ferrannini E (1992) Pathogenesis of NIDDM: a balanced overview. Diabetes Care 15: 318-368

25. Funakoshi A, Tateishi K, Shinozaki H, Matsumoto M, Wakasugi H (1990) Elevated plasma levels of pancreastatin (PST) in patients with non-insulin-dependent diabetes mellitus (NIDDM). Regul Pept 30: 159-164

26. Sánchez-Margalet V, Valle M, Lobón JA et al. (1995) Increased plasma pancreastatin-like immunoreactivity levels in non-obese patients with essential hypertension. J Hypertens 13: 251-258

27. Sánchez-Margalet V, Valle M, Lobón JA, Escobar-Jimenez F, Perez-Cano R, Goberna R (1995) Plasma pancreastatinlike immunoreactivity correlates with plasma norepinephrine levels in essential hypertension. Neuropeptides 29: 97-101

28. Ferrannini E, Buzzigoli G, Bondonna R et al. (1987) Insulin resistance in essential hypertension. N Engl J Med 317: 350-357

29. Zavaroni I, Bonora E, Pagliara M et al. (1989) Risk factors for coronary artery disease in healthy people with hyperinsulinemia and normal glucose tolerance. N Engl J Med 320: 202-206

30. Iwamoto Y, Wong KY, Goldfine ID (1981) Insulin action in cultured HTC and H35 rat hepatoma cells: receptor binding and hormone sensitivity. Endocrinology 108: 44-51

31. Hawley DM, Maddux BA, Patel RG, Wong KY, Mamula PW, Firestone GL, Brunetti A, Verspohl E, Goldfine ID (1989) Insulin receptor monoclonal antibodies that mimic insulin action without activating tyrosine kinase. J Biol Chem 264: 2438-2444

32. Goldfine ID (1987) The insulin receptor: molecular biology and transmembrane signalling. Endocr Rev 8: 235-255

33. White MF, Kahn CR (1994) The insulin signaling system. J Biol Chem 269: 1-4

34. Sánchez-Margalet V, Goldfine ID, Vlahos CJ, Sung CK (1994) Role of phosphatidylinositol-3-kinase in insulin receptor signaling: studies with inhibitor LY294002. Biochem Biophys Res Commun 204: 446-452

35. Cheatham RB, Vlahos CJ, Cheatham L, Wang L, Blenis J, Kahn CR (1994) Phosphatidylinositol 3-kinase activation is required for insulin stimulation of pp70 S6 kinase, DNA synthesis and glucose transporter translocation. Mol Cell Biol 14: 4902-4911

36. Franke TF, Yang S, Chan TO et al. (1995) The protein kinase encoded by the Akt proto-oncogen is a target of the PDGF-activated phosphatidylinositol 3-kinase. Cell 81: 727-736

37. Shepherd PR, Nave BT, Siddle K (1995) Insulin stimulation of glycogen synthesis and glycogen synthase activity is blocked by wortmannin and rapamycin in 3T3-L1 adipocytes: evidence for the involvement of phosphoinositide 3kinase and p70 ribosomal protein-S6 kinase. Biochem J 305: $25-28$

38. Sung CK, Sánchez-Margalet, Goldfine ID (1994) Role of p85 subunits of phosphatidylinositol-3-kinase as an adaptor molecule linking the insulin receptor, p62 and GTPase-activating protein. J Biol Chem 269: 12503-12507

39. Sánchez-Margalet V, Zoratti R, Sung CK (1995) Insulinlike growth factor-1 stimulation of cells induces formation 
of complexes containing phosphatidylinositol-3-kinase, guanosine triphosphatase-activating protein (GAP), and p62 GAP-associated protein. Endocrinology 136: 316-321

40. Bradford MM (1976) A rapid and sensitive method for the quantitation of microgram quantities of protein utilizing the principle of protein-dye binding. Anal Biochem 72: 248-254

41. Fleig WE, Nöther-Fleig G, Steudter S, Enderle D, Ditschuneit H (1985) Regulation of insulin binding and glycogen synthesis by insulin and dexamethasone in cultured rat hepatocytes. Biochem Biophys Acta 847: 352-361

42. Sánchez-Margalet V, Goldfine ID, Truitt K, Imboden J, Sung CK (1995) Role of p85 subunit of phosphatidylinositol-3-kinase as an adaptor molecule linking the insulin receptor to insulin receptor substrate 1. Mol Endocrinol 9: 435-442

43. Kellerer M, Mushack J, Mischak H, Häring H-U (1997) Protein kinase $\mathrm{C}(\mathrm{PKC}) \varepsilon$ enhances the inhibitory effect of $\mathrm{TNF} \alpha$ on insulin signaling in HEK293 cells. FEBS Lett 418: 119-122

44. Santos-Alvarez J, Sánchez-Margalet V (1998) Pancreastatin activates $\beta 3$ isoform of phospholipase $\mathrm{C}$ via $\mathrm{G} \alpha_{11}$ protein stimulation in rat liver membranes. Mol Cell Endocrinol 143: 101-106

45. Sanchez-Margalet V, Lobon JA, Gonzalez A, Escobarjimenez F, Goberna R (1998) Increased plasma pancreastatin-like levels in gestational diabetes subjects. Correlation with plasma catecholamine levels. Diabetes Care 21: 1951-1954

46. Reaven GM, Lithell H, Landsberg L (1996) Hypertension and associated abnormalities -the role of insulin resistance and the sympathoadrenal system. N Engl J Med 334: 374-381

47. Grasso G, Frittitta L, Anello M, Russo P, Sesti G, Trischitta $\mathrm{V}$ (1995) Insulin receptor tyrosine kinase activity is altered in both muscle and adipose tissue from non-obese normoglycaemic insulin resistant subjects. Diabetologia 38: 55-62

48. Häring HU, Mehnert H (1993) Pathogenesis of type 2 (non-insulin-dependent) diabetes mellitus: candidates for signal transmitter defect causing insulin resistance of the skeletal muscle. Diabetologia 36: 176-182

49. Velloso LA, Folli F, Sun XJ, White MF, Saad MJA, Kahn CR (1996) Cross-talk between the insulin and angiotensin signaling systems. Proc Natl Acad Sci USA 93: 12490-12495

50. Häring HU, Tippmer S, Kellerer M et al. (1996) Modulation of insulin receptor signaling. Potential mechanisms of a cross talk between bradykinin and the insulin receptor. Diabetes 45 [Suppl 1] S115-S119

51. Takayama S, White MF, Lauris V, Kahn CR (1984) Phorbol esters modulate insulin receptor phosphorylation and insulin action in cultured hepatoma cells. Proc Natl Acad Sci USA 81: 7797-7801

52. Takayama S, White MF, Kahn CR (1988) Phorbol ester-induced serine phosphorylation of the insulin receptor decreases its tyrosine kinase activity. J Biol Chem 263: 3440-3447

53. Danielsen AG, Liu F, Hosomi Y, Shii K, Roth RA (1995) Activation of protein kinase $\mathrm{C} \alpha$ inhibits signaling by members of the insulin receptor family. J Biol Chem 270: 21600-21605

54. Duronio V, Jacobs S (1990) The effect of protein kinase C inhibition on insulin receptor phosphorylation. Endocrinology 127: 481-487

55. Bossenmaier B, Mosthaf L, Mischak H, Ullrich A, Häring HU (1997) Protein kinase $C$ isoforms beta 1 and beta 2 inhibit the tyrosine kinase activity of the insulin receptor. Diabetologia 40: 863-866 